\title{
Tradisi Melaut Nelayan Muhammadiyah Pesisir Provinsi Gorontalo
}

\author{
Asruddin', Ni'mawati Syariah² \\ Program Studi Budidaya Perairan, Fakultas Ilmu-Ilmu Pertanian, Universitas Muhammadiyah \\ Gorontalo \\ Gorontalo, Indonesia \\ 'rudisiago@umgo.ac.id 2ni'ma.syariah@umgo.ac.id
}

Masyarakat di wilayah pesisir Provinsi Gorontalo merupakan masyarakat nelayan yang mayoritas beragama islam yang memiliki tradisi dan kebudayaan tersendiri. Di wilayah pesisir tersebut terdapat juga kalangan Muhammadiyah dimana sebagian warganya berprofesi sebagai nelayan. Terdapat penerapan nilai-nilai islam didalam tradisi dan kebiasaan nelayan Muhammadiyah yang berkaitan dengan kegiatan penangkapan ikan. Tujuan penelitian ini untuk mengetahui gambaran mengenai tradisi melaut nelayan muhammadiyah pesisir di Gorontalo. Metode yang digunakan dalam penelitian ini adalah metode kualitatif. Berdasarkan hasil penelitian diperoleh informasi bahwa nelayan Muhammadiyah memiliki tradisi penentuan hari baik disaat memulai penurunan perahu, memiliki doa dalam memulai kegiatan penangkapan ikan, nelayan Muhammadiyah masih memiliki kepercayaan terhadap pantangan (mitos) tertentu dan nelayan Muhammadiyah memiliki kebiasaan mengucapkan syukur atas rezeki yang diperolehnya. Ada beberapa tradisi dan kebiasaan yang mempunyai nilai-nilai islam di dalamnya, seperti membaca doa Bismillah ketika hendak melakukan kegiatan penangkapan ikan dan mengucapkan syukur Alhamdulillah ketika memperoleh rezeki hasil tangkapan ikan serta senantiasa berbagai kepada orang lain.

Kata Kunci : Tradisi melaut, Nelayan Muhammadiyah, Nilai-Nilai Islam, Pesisir Gorontalo

I. PENDAHULUAN

Indonesia dikenal sebagai negara berpenduduk muslim terbesar di dunia karena $85-90 \%$ diantaranya adalah muslim. Berbicara masalah Islam kita tidak pernah terlepas dari peranan Muhammadiyah sebagai salah satu organisasi Islam terbesar di negara ini'. Muhammadiyah adalah gerakan Islam yang didirikan oleh K.H. Ahmad Dahlan pada tanggal 8 Zulhijjah $1330 \mathrm{H}$ bertepatan dengan tanggal 18 November $1912 \mathrm{M}$, di Yogyakarta. Gerakan ini diberi nama Muhammadiyah, karena K.H. Ahmad Dahlan berharap agar dapat mencontoh jejak perjuangan Nabi Muhammad saw. Juga dimaksudkan agar semua anggota Muhammadiyah benar-benar menjadi muslim yang penuh pengabdian dan penuh tanggung jawab terhadap agamanya serta merasa bangga dengan keislamannya ${ }^{2}$.

Kondisi Indonesia sebelum Islam menyebar di kalangan masyarakat nusantara pada saat itu masih menganut paham animisme, dinamisme dan pahampaham keyakinan yang bersumber dari kebiasaan nenek moyang terdahulu. Salah satu peran organisasi Muhammadiyah dalam menyebarkan agama adalah dengan berdakwah mulai dari kalangan pemerintahan sampai kepada masyarakat tradisional. Masyarakat tradisional di Indonesia tidak terlepas dari masyarakat petani dan nelayan sebagai populasi terbanyak.

Masyarakat pesisir merupakan populasi terbanyak di Indonesia ditinjau dari segi geografis wilayah Indonesia yang merupakan wilayah kepulauan dengan 
luas wilayah perairan tiga kali luas seluruh wilayah daratan. Masyarakat nelayan merupakan masyarakat pesisir yang kehidupannya bergantung dari pemanfaatan wilayah pesisir dan laut ${ }^{3}$. Dalam pemanfaatan wilayah pesisir dan laut masyarakat nelayan memiliki nilainilai, kebiasaan, tradisi dan adat istiadat dalam memanfaatkan sumberdaya pesisir dan laut termasuk dalam melakukan penangkapan ikan. Beberapa budaya dan tradisi di Nusantara yang berkaitan dengan nelayan pesisir antara lain :

Nelayan pesisir di Kota Sibolga, sebagian besar masih mengkombinasikan norma-norma tradisional dengan aplikasi teknologi penangkapan ikan secara mutakhir sehingga pola-pola pemanfaatan, norma tradisional seperti ritual niat tahunan (tolak bala/jamu laut) dan pantangan-pantangan yang selama ini masih mewarnai perilaku komunitas nelayan cenderung sedikit memudar meski tidak terkikis sampai habis namun masih ada sebagian nelayan dan tekong yang masih percaya akan mitos-mitos, ilmu gaib yang berhubungan dengan pemanfaatan sumberdaya perairan ${ }^{4}$.

Masyarakat Mandar juga memiliki ritual ritual yang mengiringi pembuatan perahu tradisional sandeq, dapat dilihat dalam tiga tahapan utama yaitu pada awal pembuatan perahu, dalam proses pembuatan perahu dan peluncuran perahu ke laut. Makna yang terkandung dalam pelaksanaan ritual adalah merupakan pengharapan agar senantiasa diberi keselamatan oleh Allah SWT dalam menggunakan perahu. Selain itu, ritual juga bermaksud untuk memohon rezeki yang melimpah dari proses melaut nantinya. Nilai religiusitas masyarakat Mandar terlihat jelas dari setiap tahapan ritual yang dilakukan, dengan menggunakan mantra-mantra dan do"a sebagai pesan verbal yang diadopsi dari Al-Quran dan bernuansa islami. Selain itu, pesan nonverbal dalam ritual pembuatan perahu sandeq dipusatkan pada penggunaan ussul atau sistem pengetahuan masyarakat setempat yang dilakukan dengan tindakan maupun benda-benda simbolik untuk menunjukkan harapan atau keinginanannya ${ }^{5}$.

Di Belawan memiliki tahapan penyelenggaraan upacara yang diadakan yaitu proses pemancangan panji dan pembuatan balai, penyembelian hewan, menguras pantai dan mengantar persembahan, berzanji (ikrar, doa, pengumuman hari patang), makan bersama dan syukuran. dalam proses pemasangan panji-panji dan pembuatan balai berisi semua persiapan yang harus disiapkan sebelum ritual. selanjutnya proses penyembelian hewan dan mengantar persembahan yang merupakan kegiatan inti. selanjutnya kegiatan doa, pengumuman hari penting dan makan bersama merupakan penutup acara yang ditandai dengan masyarakat bernyanyi bersama dimana lagu yang dinyanyikan yaitu lancang kuning, tanjung katung, dan syair selendang delima selanjutnya menari bersama yang merupakan tanda ritual menjamu laut telah berakhir ${ }^{6}$.

Masyarakat Branta kecamatan Tlanakan Madura mengadakan ritual roket tase yang dilengkapai sesaji-sesaji sebagai sarana yang yang menghubungkan antara dunia manusia dan tuhan, sesaji tersebut menjadi simbol kepasrahan manusia terhadap kekuasaan tuhan. Sebelum melaut mereka melakukan sebuah ritual pemberangkatan yang dilakukan oleh pemangku adat yang bermakna agar hasil tangkapan melimpah dan terhindar dari malapetaka serta melakukan pesta rakyat saat usai melaut hal ini dibentuk dan dirangkai menjadi sebuah karya tari ${ }^{7}$.

Terdapat keragaman adat istiadat, budaya dan tradisi setiap wilayah pesisir oleh masyarakat nelayan baik dalam persiapan penangkapan ikan, acara syukuran atas hasil yang diperoleh, dan lain-lain. Kebiasaan tradisi-tradisi tersebut 
menjadi turun-temurun dari nenek moyang. Kebiasaan merupakan segala ilmu pengetahuan yang telah dimiliki untuk diwariskan dari satu generasi ke generasi lain yang menjadikan perilaku masyarakat dalam kehidupan sehari-hari baik terhadap mitos maupun adat istiadat.

Masyarakat pesisir di Gorontalo juga merupakan masyarakat yang memiliki keragaman budaya dan tradisi baik yang berkaitan dengan acara pernikahan, kematian, kegiatan pertanian maupun kegiatan penangkapan ikan. Tradisi yang berkaitan dengan kegiaatan penangkapan ikan seperti penentuan hari baik dalam penurunanan perahu, doa saat penurunan perahu baru yang berkapasitas besar, pantangan terhadap hal-hal yang berkaitan dengan kegiatan penangkapan ikan maupun syukuran atas perolehan hasil tangkapan ikan.

Tradisi itu sendiri merupakan perilaku yang masih memiliki kaitan dengan masa lalu yang masih dipertahankan pada masa sekarang. la menunjukkan kepada sesuatu yang diwariskan dari generasi ke generasi, dan wujudnya masih ada hingga sekarang. Oleh karena itu, secara ringkas dapat dinyatakan bahwa tradisi adalah sesuatu yang diwariskan atau ditransmisikan dari masa lalu ke masa kini. Pada umumnya tujuan penyelenggaraan suatu upacara tradisi merupakan bentuk dan sikap menghormati, mensyukuri, memuja, dan memohon keselamatan kepada Tuha ${ }^{8}$.

Penentuan hari baik yang dilakukan oleh masyarakat Gorontalo dalam hal penurunanan perahu merupakan suatu tradisi yang melanjutkan tradisi pendahulu mereka untuk dipatuhi dan diamalkan sampai sekarang. Ketaatan dan keyakinanan terhadap esensi penentuan hari baik juga merupakan suatu ikhtiar atau suatu upaya untuk menghindari halhal yang tidak diinginkan mengingat banyaknya tantangan dilaut yang dapat mengancam keselamatan nelayan. upacara tradisonal pada dasarnya berfungsi sebagai media komunikasi antara manusia dengan kekuatan lain yang ada di luar diri manusia ${ }^{8}$.

Masyarakat Gorontalo juga memiliki pantangan-pantangan yang masih diamalkan baik itu pantangan untuk menghindari suatu perkara atau pantangan yang diharuskan untuk diamalkan. Kehidupan nelayan yang berhubungan dengan laut dimana terdapat banyak bahaya yang dapat mengancam keselamatan nelayan di laut sehingga nelayan memiliki sikap kehati-hatian dalam bertindak. 'Masyarakat Bajo di Desa Torosiaje Kab. Pohuwato Provinsi Gorontalo, memiliki pantangan yang tidak boleh dilakukan agar terhindar dari malapetaka di Laut seperti tidak memakan penyu serta terdapat ritual dan sesajian buat leluhur apabila akan menangkap ikan di sekitar gugusan karang.

Selain praktek pantangan yang dilakukan oleh masyarakat Nelayan Gorontalo, juga memiliki Doa yang diamalkan yaitu doa sebelum penurunan perahu dan doa syukur atas perolehan rezeki. Kegitan Doa saat penurunanan perahu maupun doa syukur atas perolehan ikan hasil tangkapan merupakan tradisi yang non formal dimana pelaksanaannya dapat dilakukan secara perorangan dan dapat pula dilakukan bersama-sama dengan kerabat. Doa-doa yang bernafaskan islam dilakukan mengingat masyarakat Gorontalo yang mayoritas beragama islam dimana memiliki budaya dan tradisi yang bernuansa islam. ${ }^{10}$ Islam yang dipratekkan dalam kehidupan masyarakat Gorontalo, secara kasat mata adalah Islam yang tidak terpisahkan dari kehidupan kebudayaan mereka. Dengan kata lain dimana Islam diamalkan, maka saat itu pula kebudayaan masyarakat hadir dengan berbagai bentuk dan variannya.

Masyarakat diwilayah pesisir Provinsi Gorontalo, sebagian besar berprofesi sebagai nelayan dan mayoritas beragama Islam dimana sebagian 
masyarakatnya tergabung dalam organisasi Muhammadiyah maupun komunitas masyararat yang menempatkan diri sebagai bagian yang memiliki paham islam yang diamalkan oleh warga muhammadiyah. Sangat minim kajian mengenai penerapan nilai-nilai islam terhadap masyarakat muhammadiyah sehingga diangap penting untuk melakukan penelitian tentang tradisi melaut nelayan muhammadiyah pesisir Provinsi Gorontalo.

\section{METODE PENELITIAN}

Penelitisn ini dillaksanakan di Pesisir Selatan Gorontalo dan Pesisir selatan Danau Limboto dimulai pada bulan Maret sampai dengan bulan Juli 2018. Penelitian ini menggunakan metode kualitatif. Metode kualitatif adalah prosedur penelitian yang menghasilkan data deskriptif berupa data tertulis atau lisan dari orang-orang yang diamati. Berdasarkan filsafat rasionalisme bahwa suatu ilmu yang valid diperoleh dari pemahaman intelektual dan kemampuan berargumentasi secara logis. Metode kualitatif adalah metode pengumpulan data melalui pengamatan dan wawancara. Metode ini digunakan karena beberapa pertimbangan. Pertama, menyesuaikan metode kualitatif lebih mudah apabila berhadapan dengan kenyataan jamak. Kedua, metode kualitatif menyajikan secara langsung hakikat hubungan antara peneliti dan informan. Ketiga, metode kualitatif ini lebih peka dan lebih dapat menyesuaikan diri dengan banyak penajaman dengan pengaruh bersama terhadap pola-pola nilai yang dihadapi ${ }^{\prime \prime}$.

Melalaui metode kualitatif, memungkinkan peneliti untuk menata, mengkritisi, dan mengklarifikasikan data yang menarik. Dengan demikian, penelitian kualitatif ini membimbing peneliti untuk memperoleh penemuanpenemuan yang tidak terduga sebelumnya dan membangun kerangka teoritis yang baru $^{12}$. Penelitian ini dilaksanakan di
Provinsi Gorontalo baik masyarakat pesisir laut maupun pesisir Danau Limboto. Jenis data dalam penelitian ini adalah kebiasaan dan tradisi nelayan baik dalam penentuan waktu yang baik dalam awal Penurunanan kapal/perahu penangkapan ikan, Doa atau ritual dalam awal penurunan kapal/perahu penangkapan ikan, pantangan di atas kapal yang dapat merusak keyakinan memperoleh hasil tangkapan dan cara mengekspresikan rasa syukur saat memperoleh hasil tangkapan ikan.

Sumber data dalam penelitian ini adalah data primer dan data sekunder. Data primer diperoleh dari hasil wawancara, observasi, dokumentasi terhadap kebiasaan dan tradisi nelayan Muhammadiyah di Provinsi Gorontalo. Data sekunder diperoleh dari studi literatur, penelitian, dan semua data yang diperoleh dari instansi yang terkait dengan penelitian ini. Penentuan informan dalam penelitian ini, dilakukan secara purposive. Pertimbangannya bahwa informan tersebut dinilai memiliki banyak pengetahuan dan pengalaman tentang objek penelitian. Informan dalam penelitian ini terdiri atas informan kunci dan informan lainnya. Informan kunci dalam penelitian ini adalah orang-orang yang memiliki banyak pengetahuan tentang lokasi dan objek penelitian. Objek penelitian yaitu masyarakat nelayan yang secara administrasi sebagai anggota Muhammadiyah atau masyarakat nelayan yang menempatkan diri dalam pemahaman Muhammadiyah.

Teknik pengumpulan data yang digunakan dalam penelitian ini adalah Teknik sampling snowball. Teknik sampling snowball adalah suatu metode untuk mengidentifikasi, memilih dan mengambil sampel dalam suatu jaringan atau rantai hubungan yang menerus ${ }^{13}$. Responden sebagai sampel yang mewakili populasi, kadang tidak mudah didapatkan langsung di lapangan. Untuk dapat menemukan sampel yang sulit diakses, atau untuk 
memperoleh informasi dari responden mengenai permasalahan yang spesifik atau tidak jelas terlihat di dunia nyata, maka teknik sampling snowball merupakan salah satu cara yang dapat diandalkan dan sangat bermanfaat dalam menemukan responden yang dimaksud sebagai sasaran penelitian melalui keterkaitan hubungan dalam suatu jaringan, sehingga tercapai jumlah sampel yang dibutuhkan ${ }^{14}$. Dalam sampling snowball, identifikasi awal dimulai dari seseorang atau kasus yang masuk dalam kriteria penelitian. Kemudian berdasarkan hubungan keterkaitan langsung maupun tidak langsung dalam suatu jaringan, dapat ditemukan responden berikutnya atau unit sampel berikutnya. Demikian seterusnya proses sampling ini berjalan sampai didapatkan informasi yang cukup dan jumlah sampel yang memadai dan akurat untuk dapat dianalisis guna menarik kesimpulan penelitian.

Penelitian ini menggunakan analisis deskriptif kualitatif dan interpretatif. Proses analisis dimaksudkan untuk menganalisis adab-adab, teknik yang memiliki unsur riligius secara tradisi atau secara islam, kebiasaan-kebiasaan perikaku atau etika yang memiliki unsur syariat atau berdasarkan adat dan keyakinan-keyakinan atas dasar nilai-nilai kemuhammadiyaan atau kolaborasi. Penyajian hasil analisis data dalam penelitian ini, disajikan secara informal dan formal. Teknik penyajian secara informal adalah cara penyajian hasil analisis data dengan cara deskripsi katakata atau narasi, sedangkan secara formal penyajian hasil penelitian berupa tabel atau gambar.

\section{HASIL PENELITIAN DAN PEMBAHASAN}

A. Tradisi dan Kebiasaan Nelayan Muhammadiyah Gorontalo

a) Penentuan hari baik dalam penurunan perahu/kapal
Penentuan hari baik oleh nelayan Muhammadiyah di Gorontalo merupakan suatu upaya untuk menghindari resikoresiko buruk yang akan dihadapi di lautan melaui pendekatan perhitungan hari dan bulan. Penentuan hari baik dengan pendekatan perhitungan hari dan bulan, apabila dipandang dari sudut agama maka hal tersebut terdapat nilai spriritual yang tersirat di dalam tradisi tersebut. Perhitungan hari dan bulan merupakan ilmu perbintangan dalam memprediksi pasang atau surutnya air laut. ${ }^{15}$ pada saat pasang perbani kedudukan matahari dan bulan terhadap bumi membentuk sudut 90 derajat, sehingga gaya yang bekerja saling melemahkan dan terbentuk julat pasang yang kecil.

Penentuan hari baik di dalam penurunanan perahu dapat dikatakan sebagai kolaborasi antara tradisi mempertahankan kebiasaan pelaut pendahulu mereka dengan penerapan nilai agama. Nilai agama yang dimaksudkan adalah adanya usaha nelayan untuk menghindari resiko-resiko buruk dengan perhitungan ilmu astronomi atau ilmu perbintangan. Usaha-usaha yang dilakukan tersebut merupakan ikhtiar dan bagian dari etos kerja sebagaimana yang dijelaskan di dalam QS. Al-Taubah (9): 105. Surah at-Taubah ayat 105 memerintahkan untuk berusaha dan bekerja dimana setiap usaha yang dilakukan, pasti akan diketahui oleh Allah SWT, serta setiap perbuatan seseorang baik maupun buruk kelak di akhirat akan akan diperlihatkan secara transparan apa adanya, baik yang tersembunyi maupun yang tampak ${ }^{16}$.
b) Doa penurunan peralatan penangkapan

Doa-doa yang digunaakan oleh nelayan Muhammadiyah pada saat hendak melakukan kegiatan penangkapan ikan maupun pada saat menurunkan perahu merupakan upaya memohon kepada sang pencipta untuk senantiasa dilindungi dan diberkahi kegiatan penangkapan ikan yang 
dilakukannya. Nelayan Muhammadiyah di wilayah pesisir Danau Limboto dan beberapa nelayan Pesisir Laut Gorontalo melakukan doa dengan ucapan "Bismillahirrahmanirrahim"dengan harapan diberi perlindungan dan diberkahi kegiatannya oleh sang Pencipta. Doa yang digunakan oleh nelayan hampir sama dengan doa slamatan di klaten Jawa tengah yang juga menggunakan doa pembuka dengan ucapan bismillah walau masyarakat klaten Jawa Tengah masih memiliki tradisi yang bercorakan sinkretis $^{17}$, juga masyarakt Melayu Sarawak menggunakan pembukaan doa dalam perobatan tradisional dengan ucapan bismillahirrahmnirrahim walaupun intisari doanya masih menggunakan bahasa lokal ${ }^{18}$.

oleh nelayan Mismillahirrahmanirrahim Gorontalo memiliki unsur Islam dalam meminta perlindungan kepada Allah. ${ }^{19}$ penting untuk membaca bismillah atau bismillahirrahmanirrahim dalam segala perkara yang bermanfaat. Faedah lain dengan membaca bismillah, pembaca tersebut akan dijaga dari gangguan setan. Sejalan dengan Keputusan Muktamar Muhammadiyah Ke-44 (2000), dikatakan bahwa selayaknya Pola tingkah laku warga Muhammadiyah dalam menjalani kehidupan sehari-hari merupakan nilai dan norma yang bersumber dari AlQur'an dan Sunnah.

Sebagian nelayan Muhammadiyah di pesisir Gorontalo yaitu di Kampung Tenda, memiliki tradisi tambahan selain doa bismillah dalam memulai kegiatan penangkapan ikan. Tradisi tambahan tersebut yaitu apabila akan menurunkan perahu baru yang berkapasitas besar yang biasa diistilahkan "kapal", maka akan ada doa dan sesajian berupa dedaunan, makanan dan air. Pembaacaan doa dilakukan oleh imam atau orang yang sering dipercayakan membacakan doa keselamatan dimana doa-doanya berupa salawat-salawat nabi yang bersumber dari
Al-Qur'an. Tradisi tersebut memiliki sedikit kemiripan dengan tradisi peluncuran perahu etnit mandar. Tradisi peluncuran perahu oleh masyarakat mandar menggunakan doa-doa keselematan dalam peluncurannya serta terdapat sesajian yang ada di atas perahu tersebut ${ }^{5}$.

Berdasarkan tradisi Doa dan Sesajian di atas perahu tersebut merupakan tradisi pendahulu mereka yang tetap masih dipertahankan oleh nelayan. Ada perpaduan antara tradisi dan nilai-nilai islam pada acara doa tersebut. Unsur tradisi merupakan kebiasaankebiasaan pendahulu mereka yang masih tetap diamalkan oleh nelayan. disamping itu ada kolaborasi antara berbagai kalangan karena di daaerah Kampung Tenda terdapat kalangan Muhammadiyah yang hidup rukun dengan kalangan yang bukan Muhammadiyah. Dibeberapa tempat di Nusantara juga terdapat kolaborasi tradisi dimana terdapat banyak kalangan yang terlibat di dalamnya, seperti ${ }^{20}$ di Desa Probur Utara, Nusa Tenggara Timur dimana mereka menempatkan keyakinan individual di ruang privat sementara tradisi dan budaya dibiarkan hidup subur di ruang publik yang menjadi milik mereka bersama sehingga memantik terjalinnya kerja sama dan kolaborasi berbagai kegiatan sosial dan keagamaan.

Tradisi doa dalam penurunan perahu oleh masyarakat di Kampung Tenda, masih memiliki Nilai-nilai islam dalam penerapannya karena bacaan yang digunakan dalam Doa tersebut berupa salawat nabi dan doa yang bersumber dari Al-Qur'an.

\section{c. Pantangan dan mitos nelayan}

Nelayan Pesisir Gorontalo baik itu masyarakat yang berda pada daerah basis Muhammadiyah maupun bukan, keberadaan mitos maupun pantanganpantangan yang berkaitan dengan kegiatan penangkapan ikan tetap masih mewarnai kehidupan nelayan tersebut. Sebagian 
nelayan yang ada di pesisir Gorontalo baik di pesisir selatan maupun pesisir Danau Limboto masih meyakini beberapa pantangan maupun mitos yang berkaitan dengan kegiatan penangkapan ikan.

Terdapat sisi baik dari keyakinan akan mitos atau pantangan tersebut karena akan membentuk sebuah keyakinanan dan aturan yang tidak tertulis dikalangan masyarakat dan hal tersebut akan menjadi kontrol dalam menjaga keseimbangan sumberdaya alam. ${ }^{21} \mathrm{Hasil}$ penelitian pada masyarakat Bajo, di Buton, Mitos menjadi pemicu semangat pada diri masyarakat sehingga tetap giat menggeluti aktivitas mereka sebagai pelaut dan ${ }^{9}$ hasil penelitian Masyarakat Bajo Desa Torosiaje Provinsi Gorontalo juga memiliki kearifan lokal berupa sejumlah tradisi, aturan atau pantangan yang masih berlaku secara turun temurun yang dipraktekkan, dipelihara dan ditaatinya sehingga sumberdaya dan ekosistem mangorve, padang lamun dan terumbu karang masih terpelihara dan dijaga dengan baik.

Sebagian pantangan dan mitos yang diyakini oleh masyarakat nelayan ada yang bersifat positif dan ada pula yang bersifat negatif. Berdasarkan Keputusan Muktamar Muhammadiyah Ke-44 (2000), sejatinya Setiap muslim yang berjiwa mu'min, muhsin, dan muttaqin, yang paripuma itu dituntut untuk memiliki keyakinan (aqidah) berdasarkan tauhid yang istiqamah dan bersih dari syirk, bid'ah, dan khurafat; memiliki cara berpikir (bayani), (burhani), dan (irfani); dan perilaku serta tindakan yang senantiasa dilandasi oleh dan mencerminkan akhlaq al karimah yang menjadi rahmatan li-`alamin.

\section{d. Pelaksanaan syukuran perolehan hasil tangkapan

$$
\text { Masyarakat nelayan }
$$

Muhammadiyah di Gorontalo memiliki kebiasaan mengucapkan "Alhamdulillah" ketika memperoleh rezeki berupa hasil tangkapan. Nelayan Muhammadiyah di Gorontalo juga memiliki jiwa sosial yang tinggi, hal ini dapat dilihat dari sikap nelayan pesisir dimana terdapatnya kebiasaan memberi sebaagian kecil hasil tangkapannya kepada orang yang meminta pada saat bongkar muatan di pelabuhan. Kebiasaan memberi dapat pula dijumpai di wilayah pesisir Danau Limboto yaitu nelayan sering bersedekah hasil tangkapannya kepada tetangganya. Kebiasaan tersebut terdapat nilai-nilai islam yang masih diterapkan dalam kehidupan masyarakat nelayan muhammadiyah di Provinsi Gorontalo. ${ }^{22}$ Sedekah dapat membuka pintu rezeki dimana sedekah tidak mengurangi harta justru sebaliknya, sedekah akan melipatgandakan sebanyak sepuluh kali lipat sebagaimana Firman Allah swt. Dalam QS. At- Taubah,[9]:99).

Berdasarkan

Keputusan Muktamar Muhammadiyah Ke-44 (2000), Islam mengajarkan agar setiap muslim menjalin persaudaraan dan kebaikan dengan sesama seperti dengan tetangga maupun anggota masyarakat lainnya masing-masing dengan memelihara hak dan kehormatan baik dengan sesama muslim maupun dengan non-muslim, dalam hubungan ketetanggaan bahkan Islam memberikan perhatian sampai ke area 40 rumah yang dikategorikan sebagai tetangga yang harus dipelihara hakhaknya.

Berbagai tradisi nelayan di nusantara dalam mengekspresikan rasa syukur mereka yang dibingkai dalam sebuah tradisi seperti di daerah pesisir Teluk Lampung Kota Bandar memiliki Tradisi Upacara Budaya Nadran (sebagai ucapan rasa syukur dan terima kasih terhadap Tuhan Yang Maha Esa yang telah melimpahkan rezeki berupa kekayaan laut yang melimpah kepada para nelayan dan dilakukan dengan cara saling bergotong royong serta saling bahu-membahu antar sesama nelayan. Tradisi upacara Nadran di dalam proses pelaksanannya, diawali 
dengan pemotongan kepala kerbau dan pemotongan nasi tumpeng yang dimuat dalam sebuah Replika Perahu atau Meron yang akan dilarung di tengah laut dan ditenggelamkan serta diperebutkan oleh seluruh warga masyarakat.

\section{KESIMPULAN}

Masyarakat yang berada di wilayah selatan pesisir laut dan wilayah selatan pesisir Danau Limboto terdapat kebiasaan-kebiasaan nelayan Muhammadiyah yang sering dilakukan dan diamalkan. Kebiasaan-kebiasaan nelayan yang berkaitan dengan kegiatan penangkapan ikan seperti terdapat kebiasaan penentuan hari baik ketika hendak menurunkan perahu, Terdapat Doa yang dipimpin oleh seorang imam disertai dengan beberapa jamuan di atas kapal, Terdapat pantangan serta mitos yang yang masih diyakini oleh nelayan dan terdapat budaya mensyukuri nikmat ketika memperoleh hasil tangkapan ikan. Penerapan nilai-nilai islam didalam kebiasaan-kebiasaan nelayan Muhammadiyah di Provinsi Gorontalo antara lain:

I. Pelaksanaan tradisi penentuan hari baik saat hendak melakukan penurunan perahu oleh nelayan masih memiliki nilainilai islam. Niai-nilai islam terdapat pada upaya dan usaha yang dilakukan oleh nelayan yaitu ikhtiar dengan memprediksi cuaca berdasarkan perhitungan perbintangan atau perhitungan secara astronomi tetapi didalam penentuan hari baik tersebut masih terdapat perpaduan keyakinanan terhadap hari yang memiliki hari-hari keberuntungan.

2. Terdapat kebiasaan berdoa yang dilakukan oleh nelayan Muhammadiyah sebelum memulai kegiatan penangkapan ikan. Mayarakat nelayan menerapkan nilai-nilai islam di dalam tradisi doa tersebut karena isi dari doa yang diucapkan adalah kalimat bismillahirrahmanirrahim. Apabila ada kapal baru yang akan diluncurkan pertama kalinya (peluncuran perdana) maka tradisi berdoa akan dipimpin oleh imam. Akan disiapkan beberapa jenis makanan, daun dan air yang akan menyempurnakan tradisi berdoa tersebut. Setelah selesai berdoa, air yang sudah dibacakan doa tersebut kemudian akan dipercikkan kebagian-bagian badan kapal.

3. Mayarakat nelayan Muhammadiyah masih mengamalkan dan meyakini beberapa pantangan-pantangan (mitos). Pantanganpantangan yang diamalkan dan diyakini antara nelayan pesisir laut memiliki sedikit perbedaan dengan nelayan pesisir danau.

4. Kebiasaan nelayan dalam mengungkapan syukur atas perolehan hasil tangkapan ikan memiliki nilai-nilai islam. Nilai-nilai islam tersebut berupa ucapan Alhamdulillah (Segala Puji Bagi Allah) dan menyisihkan sebagian kecil hasil tangkapannya untuk dibagikan kepada tetangga nelayan maupun orang lain.

\section{DAFTAR PUSTAKA}

[I] Suwarno, (200I). Muhammadiyah Sebagai Oposisi, Yogyakarta: UII Press, hlm. I.

[2] Gunawan, A dan Nurjulianti,D (ed.), (1999). Gerakan Keagamaan Dalam Penguatan Civil Society: Analisis Perbandingan Visi dan Misi LSL Ormas Berbasis Keagamaan, Jakarta.

[3] Nikijuluw, V.P.H. (200I). Potensi dan sosial ekonomi masyarakat pesisir serta strategi pemberdayaan mereka dalam konteks pengelolaan sumberdaya pesisir secara terpadu. Makalah. Pelatihan Pengelolaan Pesisir Terpadu. Proyek Pesisir, Pusat Kajian Sumberdaya Pesisir dan Laut, Institut Pertanian Bogor, Bogor.

[4] Nababan,E.JV. (2009). Tekong (studi deskriptif terhadap pengelolaan sumberdaya alam pesisir pada masyarakat Sibolga). Skripsi departemen antropologi fakultas ilmu sosial dan imu politik universitas sumatera utara. Medan.

[5] Amrullah, M. (20I5). Representasi Makna Simbolik Dalam Ritual Perahu Tradisional Sandeq Suku Mandar Di Sulawesi Barat. Skripsi. Jurusan IImu Komunikasi Fakultas IImu Sosial dan Ilmu Politik Universitas Hasanuddin.

[6] Sitanggang. O.W. (2016). Bentuk Penyajian dan Makna Musik Ritual Menjamu laut yang dilaksanakan oleh nelayan di belawan sumatera utara skripsi. Jurusan Sendratasik Fakultas Bahasa dan Seni Universitas Negeri Medan.

[7] Salawati. B. (20|4). Proses penciptaan a'biring bone $\mathrm{Di}$ kampung kunyi' desa Bahorea kecamatan Bontosikuyu kabupaten Kepulauan 
selayar sulawesi Selatan. jurnal. Program studi penciptaan dan pengkajian seni pascasarjana ISI Surakarta. Vol. I3(I).

[8] Rahman, M, G, (20I2), Tradisi Molonthalo Di Gorontalo. Jurnal Al- Ulum. Vol. I2(2),437-456.

[9] Utina. R. (20/2). Kecerdasan ekologis dalam kearifan lokal masyarakat Bajo Desa Torosiaje Provinsi Gorontalo. Prosiding Konferensi Dan Seminar Nasional Pusat Studi Lingkungan Hidup Indonesia Ke 2 I. Mataram.

[10]Mashadi (20I2), Realitas Adati Hula-Hulaa To Syara'i, Syara'i Hula-Hulaa To Qur'ani, Jurnal Al- Ulum, Vo. 12 (I) Hal. 20I-222.

[I I]Maleong \& Lexy ]. (2004). Metode Penelitian Kualitatif. Bandung : PT Remaja Posdakarya.

[12]Endraswara dan Suwardi. (2003). Metodologi Penelitian Kebudayaan. Yogyakarta : Gadjah Mada University press.

[13]Neuman, W. L. (2003). Social Research Methods, Qualitative and Quantitative Approaches. Fifth Edition. Boston: Pearson Education.

[14]Nurdiana. N, 20I4. Teknik sampling snowball Dalam penelitian lapangan ComTech Vol. $5 \mathrm{No}$. 2: $11110-1118$

[15]Qomar.M. (20I5). Ragam Identitas Islam di Indonesia dari Perspektif Kawasan. Jurnal. Epistemé, vol. 10( 2)

[16]Sitepu.N.I, (2015) Etos Kerja Ditinjau Dari Perspektif Alquran Dan Hadis. Jurnal Perspektif Ekonomi Darussalam Vol. I(2).

[17]Sutiyono. (2011) tradisi masyarakat sebagai kekuatan sinkretisme di trucuk, klaten, Jurnal Penelitian Humaniora, Vol. 16(1).

[18]Rodi. R. C, Musa.H, Muhammad. S.J.N, Soh. N.A.C, (20|4), Konsep Kebenaran Ilmu dalam Bahasa Melayu Berpaksikan Pandangan Islam yang Sejagat. Internasional Jurnal of the malay World and Civilisation (Iman) Vol. 2(I).

[19]Romlah. (2012). Pendidikan Islam Informal Penerbit: Harakindo Publishing. Bandar Lampung

[20]Manan.M.A, (2018). Kerukunan Berlandaskan Tradisi dan Toleransi Keberagamaan: Pembelajaran dari Komunitas Desa Probur Utara, Nusa Tenggara Timur. Jurnal Masyarakat \& Budaya, Vol. 20( 1).

[2I]Uniawati. (2011). Mitos dan Aktivitas Melaut Masyarakat Bajo di Buton. Metasastra, Vol. 4 (1)

[22]Saadiyah. (2014). Sedekah dalam pandangan Al kuranRausyan Fikr, Vol. 10(2)

[23]Nur'aini, N. Wakidi dan Basri, M (20|4). Tradisi upacara nadran pada masyarakat Nelayan cirebon di kelurahan Kangkung bandar lampung. Jurnal FKIP Unila. Vo.2(6). 